\title{
Effect of Nicotine on STAT1 Pathway and Oxidative Stress in Rat Lungs
}

\author{
Aida Abdeen Mahmoud*1, Hekmat Osman Abdel-Aziz², \\ Mohamed Elbadr ${ }^{3}$, Hala Elbadre ${ }^{4}$
}

\begin{abstract}
Background: Tobacco use is responsible for millions of preventable deaths due to cancer. Nicotine, an alkaloid chemical found in tobacco was proved to cause chronic inflammation and oxidative stress. The transcription factor STAT1 induces the expression of many proinflammatory genes and has been suggested to be a target for anti-inflammatory therapeutics. The following study investigated the effect of Nicotine on STAT1 pathway and oxidative stress in rat lung tissue.

Methods: Thirty rats were divided into 3 groups; group I considered as control, group II; its rats were daily injected with Nicotine at a dose of $0.4 \mathrm{mg} / 100$ gm body for 8 successive weeks and group III; its rats were daily injected with Nicotine as group II, but the injection was stopped for another 4 weeks. STAT1 $\alpha$ protein was assessed by immunohistochemistry, COX-2 and iNOS genes expression were evaluated by real time PCR and thiobarbituric acid reactive substances (TBARS) and total thiols were measured using spectrophotometric methods in the lung tissues of the rats.

Results: The results of the study revealed that group II rats had the highest expression of STAT1 $\alpha$ protein and COX-2 and iNOS genes and oxidative stress in their lung tissues. Nicotine cessation for 4 weeks caused a marked reduction in the expression of STAT1 $\alpha$ protein, COX-2 and iNOS genes and oxidative stress.

Conclusions: Induction of STAT1 pathway and the increase in oxidative stress may be the mechanisms through which Nicotine may induce its harmful effects.
\end{abstract}

Keywords: COX-2, iNOS, Nicotine, Oxidative stress, STAT1.

\section{Introduction}

Tobacco leaves used for smoking contain an abundant amount of the alkaloid chemical, Nicotine (1). Proliferation, angiogenesis and growth of tumors was observed in cell lines of non- small cell lung cancer (NSCLC) and animal models of NSCLC on exposure to Nicotine (2). Furthermore, oxidative stress and apoptosis can be triggered by Nicotine in many cell types and tissues (3). For example, cigarette smoke induces apoptosis mediated by reactive oxygen species in rat gastric mucosa (4).

STAT1 is a member of the STAT (Signal transducer and activator of transcription) family of proteins. These proteins act as transcription factors as their phosphorylation causes their activation, dimerization and translocation to the nucleus. STAT1 protein can be activated by several ligands such as Interferon alpha (IFN $\alpha$ ), Interferon gamma (IFN $\gamma$ ), Epidermal Growth Factor (EGF), Platelet Derived Growth Factor (PDGF), IL-6 and IL-27 (5). Many physiological processes like immune response, proliferation, apoptosis, and cell survival are regulated by STAT1 (6). STAT1 expression increases in response to oxidative stress and inflammatory stimuli (7). Alternative splicing 
generates 2 naturally occurring isoforms of STAT1: STAT1 $\alpha(91 \mathrm{kDa})$ and STAT1 $\beta$ (84 $\mathrm{kDa}$ (8). STAT1 $\alpha$ is considered the active isoform of STAT1 that regulates cell growth and apoptosis (9). Cyclooxygenase 2 (COX-2) is an inducible enzyme expressed in immune cells and catalyzes the synthesis of proinflammatory prostaglandins (mainly PGE2) from arachidonic acid. Prostaglandins trigger the production of many proinflammatory chemokines and cytokines (10). Inducible nitric oxide synthase (iNOS, encoded by NOS2A) produces NO in response to environmental stimuli, which can result in nitrosative stress. (11). STAT1 mediates COX2 and iNOS expression $(12,13)$.

The present study evaluated the effect of Nicotine injection and its cessation on STAT1 $\alpha$ protein expression, the gene expression of COX-2 and iNOS, lipid peroxides and tiol group content in rat lung tissues.

\section{Materials and Methods}

\section{Animals and experimental design}

Thirty healthy male albino rats weighing from 200 to $250 \mathrm{gm}$ were housed in clean and adequately ventilated cages under the same environmental conditions, fed a standard laboratory food and water ad libitum. The rats were divided into 3 groups of 10 rats as following: control group (Group I) was received saline by subcutaneous injection, Nicotine Treated Group (Group II) was injected subcutaneously with Nicotine (in the form of powder, dissolved in distilled water, Sigma chemical company) in a dose of 0.4 $\mathrm{mg} / 100$ gm body weight daily for 8 successive weeks (14) and Nicotine cessation group (Group III) was injected subcutaneously with the same dose of Nicotine as group II (0.4 $\mathrm{mg} / 100 \mathrm{gm}$ body weight daily) for 8 weeks, then Nicotine injection stopped for 4 weeks. At the end of the study, the rats were sacrificed using ether inhalation as an anesthetic and carefully dissected and the lungs on both sides were removed. Tissues from both lungs were used for RNA extraction, determination of lipid peroxides and total thiol group and preparation of paraffin blocks for immunohistochemistry.

\section{Real- time PCR assay of COX-2 and iNO synthase gene expression:}

RNA was extracted from lung tissues using RNA extraction kit (PureLink ${ }^{\mathrm{TM}}$ RNA Mini Kit). Total RNA was reverse transcribed to cDNA using High-Capacity cDNA Reverse Transcription Kit, according to the manufacturer's instructions. The amplification of cDNA was done using the primers mentioned in Table 1. A reaction mixture of 25 $\mu \mathrm{L}$ containing 1 X SYBR $®$ Green PCR Master Mix, forward and reverse primers and the $\mathrm{c}$ DNA was prepared and amplified using StepOne real time PCR apparatus, applying the following cycling conditions: $95{ }^{\circ} \mathrm{C}$ denaturation step for $2 \mathrm{~min}$ followed by 40 cycles of $95{ }^{\circ} \mathrm{C}$ for $15 \mathrm{sec}$ then, $60{ }^{\circ} \mathrm{C}$ annealing and extension for $60 \mathrm{sec}$. The housekeeping gene GAPDH was used to normalize the quantities of the target genes. Data were calculated using comparative $2^{-}$ $\Delta . \Delta . \mathrm{CT}$ method.

Table 1. primers used for gene expression assay.

\begin{tabular}{llll}
\hline Transcript & Forward primer & Reverse primer & $\begin{array}{l}\text { product } \\
\text { length }\end{array}$ \\
\hline COX-2 & 5- GATGACGAGCGACTGTTCCA-3' & 5'- TGGTAACCGCTCAGGTGTTG -3 & 98 bp \\
iNOS & 5'- AGAATCCCTGGACAAGCTGC-3' & 5'-CTTGTGGTGAAGGGTGTCGT-3' & 106 bp \\
GAPDH & 5'-CCCCATAACAACAGGAGGGG -3 & 5'-CCCATAACCCCCACAACACTG-3' & 111 bp \\
\hline
\end{tabular}

\section{Immunohistochemistry of STAT1 protein}

Using the STAT1 alpha p91 (C-111) antibody (Santa Cruz Biotechnology, Inc.), we performed immunohistochemistry and the staining results were independently evaluated. For the quantification of immunohistochemistry, STAT1 alpha p91 
strongly positive stained cells were counted in ten high power fields in each rat using the light microscope Leica ICC50 Wetzlar (Germany) at the Histology Department, Faculty of Medicine, Sohag University.

\section{Assay of Oxidative stress}

Tissue was homogenized (10\%, w/v) in ice-cold sucrose buffer $(0.25 \mathrm{M})$ and then centrifuged at $10,000 \mathrm{x}$ g for $20 \mathrm{~min}$ at $4{ }^{\circ} \mathrm{C}$ and the supernatant was used for assay of lipid peroxides and total thiol.

\section{Lipid Peroxidation assay}

The lipid peroxides were determined using the reaction between thiobarbituric acid (TBA) and malonyldialdehyde (MDA). Two molecules of TBA react with one molecule of MDA and 2 molecules of water are removed. A red chromophore will be formed that absorbs light at $532 \mathrm{~nm}$. Results were expressed as nanomoles of MDA/g tissue (15).

\section{Thiol group assay}

Modified Ellman's method was used to measure thiol levels. 7 5, 5'-dithiobis-2nitrobenzoic acid (DTNB) reacts with thiol compounds (-SH groups) to give a yellowish complex, which is measured at $520 \mathrm{~nm}$. The values were expressed as nmole of reduced thiol/gm tissue (16).

\section{Statistical analysis}

Data were represented as mean \pm SD. Analysis of variance (ANOVA), followed by Tukey's Multiple Comparison Test was used to compare the data of the different groups. Pearson correlation analysis was used in the study. P-values less than 0.05 were considered significant.

\section{Results}

This study evaluated the effect of Nicotine injection and its cessation on the expression of STAT $1 \alpha$ protein, the gene expression of $C O X$ 2 and $i N O$ synthase, lipid peroxides and $-\mathrm{SH}$ group in the lung tissues of rats.

\section{The gene expression of $\mathrm{COX}-2$ and $i N O$ synthase}

As indicated in Table 2; the expression of COX-2 and iNOS genes increased in lung tissues of group II (Nicotine Treated Group) compared to group I $(\mathrm{p}<0.0001)$. Nicotine stoppage in group III resulted in a marked reduction in the gene expression of the two studied genes compared to group II rats $(\mathrm{p}<$ 0.0001 ). A strong positive correlation was found between $C O X-2$ and $i N O S$ genes expression in group II rats $(\mathrm{r}=0.885)$.

Table 2. Gene expression of $C O X-2$ and $i N O S$

\begin{tabular}{cccc} 
& \multicolumn{2}{c}{ Table 2. Gene expression of COX-2 and $i N O S$} & \\
\cline { 2 - 4 } & Group I $(\mathbf{n}=\mathbf{1 0})$ & Group II $(\mathbf{n}=\mathbf{1 0})$ & Group III $(\mathbf{n = 1 0})$ \\
\hline iNOS & $1.06 \pm 0.06$ & $3.98 \pm 0.58^{* * * \mathrm{a}}$ & $2.3 \pm 0.4^{* * * \mathrm{~b}}$ \\
COX-2 & $1.05 \pm 0.04$ & $5.08 \pm 0.51^{* * * \mathrm{a}}$ & $3.1 \pm 0.52^{* * * \mathrm{~b}}$
\end{tabular}

${ }^{* * * a} \mathrm{p}<0.0001$, compared to group I, ${ }^{* * * b} \mathrm{p}<0.0001$, compared to group II

\section{Histomorphometric results of STAT1 $\alpha$ protein immunohistochemistry}

As shown in Table 3 and figures (1, $2 \& 3)$; the mean number of STAT1 $\alpha$ protein strongly positive stained cells per ten high power fields (cells/HPF) in lung tissues of group II rats was significantly higher than in group I rats $(\mathrm{p}<0.0001)$. In group III rats, the number of cells was significantly fewer than in group II rats. Positive correlations were found between the number of positively stained cells and the expression of COX-2 and iNOS genes ( $\mathrm{r}=$ $0.83 \& 0.85$, respectively). 
Table 3. Mean number of cells strongly positive for STAT1 $\alpha$ protein.

\begin{tabular}{cccc}
\cline { 2 - 3 } & Group I $(\mathbf{n}=\mathbf{1 0})$ & Group II $(\mathbf{n}=\mathbf{1 0})$ & Group III $(\mathbf{n}=\mathbf{1 0})$ \\
\hline Number of cells (cells/HPF) & $7 \pm 2.1$ & $54 \pm 6.7^{* * * a}$ & $13 \pm 2.2^{* * * 6}$ \\
\cline { 2 - 3 } & &
\end{tabular}

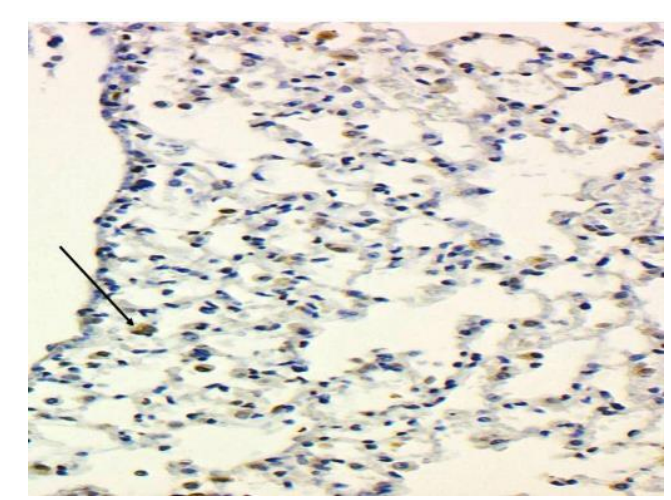

Fig. 1. photomicrograph of rat lung of the control group immunostained with STAT 1 antibody showing few positive stained cells (arrow) as cytoplasmic brownish coloration (STAT -1 immunostaining X200).

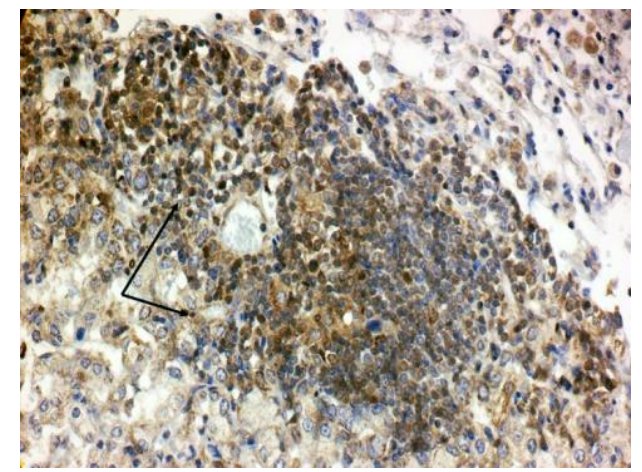

Fig. 2. photomicrograph of rat lung of the Nicotine treated group immunostained with STAT1 antibody showing many positive stained cells (arrow), (STAT1 immunostaining X200).

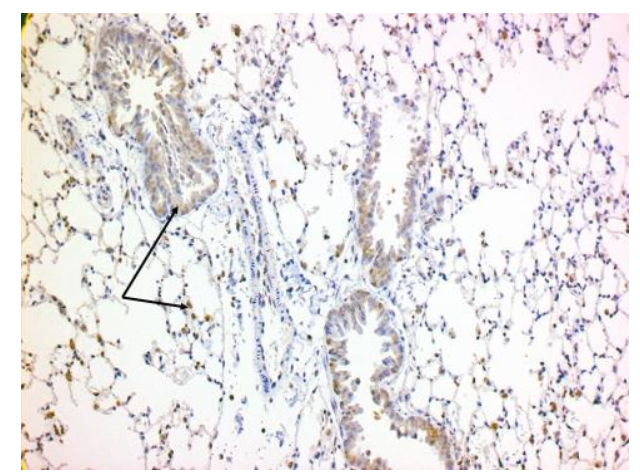

Fig. 3. photomicrograph of rat lung of the Nicotine stoppage (Recovery group) immunostained with STAT1 antibody showing decreased number of positive stained cells (arrow) (STAT1 immunostaining X200).

\section{Oxidative stress markers}

As shown in Table 4, TBARS levels increased significantly in lung tissues of group II rats compared to groups I rats $(\mathrm{p}<0.001)$. Nicotine cessation in group III rats led to a marked reduction in TBARS compared to group II ( $\mathrm{p}<$ 0.001). Regarding total thiols, group II rats had the lowest levels of these compounds compared to both of groups I and III. 
Table 4. Oxidative stress markers levels.

\begin{tabular}{|c|c|c|c|}
\hline & Group I $(n=10)$ & Group II $(n=10)$ & Group III $(n=10)$ \\
\hline $\begin{array}{l}\text { TBARS (n mole MDA/ } \\
\text { g tissue) } \\
\text { Total Thiols ( } \mathrm{n} \text { mole } \\
\text { thiol/gm tissue) }\end{array}$ & $\begin{array}{l}32 \pm 4.595 \\
5.84 \pm 0.5275\end{array}$ & $\begin{array}{l}74.1 \pm 6.607^{* * a} \\
3.26 \pm 0.2989^{* * a}\end{array}$ & $\begin{array}{l}50.3 \pm 3.945^{* * \mathrm{~b}} \\
4.38 \pm 0.2658^{* * \mathrm{~b}}\end{array}$ \\
\hline
\end{tabular}

\section{Discussion}

This study evaluated the effect of Nicotine and its cessation on STAT1 $\alpha$ protein expression, oxidative stress markers and $C O X-2$ and $i N O S$ genes expression in the lungs of male albino rats. The study revealed that injection of the rats with Nicotine for 8 successive weeks caused significant elevation in STAT1 $\alpha$ protein, oxidative stress, and COX-2 and iNOS genes expression in their lung tissues compared to the control group. In case of Nicotine cessation for 4 weeks, decreased levels of STAT $1 \alpha$ protein, oxidative stress, and COX-2 and iNOS genes expression in lung tissues was observed compared to the Nicotine treated group.

In accordance with our results, Exposure of Nicotine was found to cause activation of alveolar macrophages and airway epithelial cells that released proinflammatory cytokines and infiltrated the lungs by inflammatory cells. In addition, Nicotine enhanced the growth of multiple cancer types (3). At the same time, cigarette smoke inhibited normal tissue repair role played by fibroblasts $(17,18)$.

In our study, the elevated levels of STAT1 $\alpha$ protein was associated with an increase in the levels of iNOS and COX-2 genes expression and oxidative stress in lung tissues. Similarly, STAT1 has been proved to promote proinflammatory cytokines and chemokines that contribute to tumerogenesis through iNOS and COX-2 genes (19). Moreover, STAT1 promoted skin tumors through enhancing iNOS and $C O X-2$ genes (20).

COX-2 is an enzyme that possesses multiple functions associated with cellular proliferation and apoptosis (21). Nicotine was reported to enhance the expression and activity of this enzyme and to increase the release of prostaglandin E2 and thromboxane A2 (22). Prostaglandin E2 has proinflammatory actions that promotes tumor growth and thromboxane A2 helps in platelet activation and angiogenesis (23).

iNOS is present in all nucleated mammalian cells and induced by cytokines or endotoxins. NO mediates tissue injury in pathophysiological states, however it is an important signaling molecule (24). Nicotine was reported to potentiate IFN $\gamma$ - induced cytotoxic effects by enhancing NO production

and enhancing iNOS gene expression, indicating a strong association between inflammation and smoking (25).

In the present study, Nicotine increased lipid peroxides and decreased thiol groups in rat lung tissue. Many authors reported the oxidative stress effect of Nicotine, for example, an increase in lipid peroxides was found in hamster ovary cells and rat pancreatic tissue after incubation with Nicotine $(26,27)$. Also, intraperitoneal nicotine-administered rats had an elevated lipid peroxides in their tissues compared to control rats $(28,29)$. In addition, increased lipid peroxidation was reported in the blood of smokers $(30,31)$. Lipid peroxides are produced by long-chain fatty acid peroxidation and have a role in the modification of lipoproteins (32). Thiols represent fundamental antioxidant defense mechanisms of the cells because of their selective interaction with reactive oxygen and nitrogen species $(33,34)$

When, rats were subjected to cessation of Nicotine for 4 weeks a decrease in STAT1 $\alpha$ protein, COX-2 and iNOS genes expression and oxidative stress occurred. In accordance 
with these results, sputum of smokers was found to have higher neutrophil content compared with nonsmokers and that count decreased 6 weeks after smoking cessation $(35,36,37)$ However, another study reported no change in the sputum of smokers 4 weeks after smoking cessation (38). Others reported that the reduction of the number of cigarettes per day by more than $50 \%$, decreased bronchoalveolar lavage macrophages and neutrophils after 2 months $(39,40)$.

Nicotine enhances inflammation and oxidative stress, reported in our study as the increase in STAT1 $\alpha$ protein expression, $C O X$ 2 and iNOS genes expression and lipid pexides and a decrease in thiol group in lung tissues of Nicotine-injected rats. Nicotine cessation for 4 weeks significantly improved the

\section{References}

1. Counts ME, Morton MJ, Laffoon SW, R H Cox, P J Lipowicz. Smoke composition and predicting relationships for international commercial cigarettes smoked with three machine-smoking conditions. Regul Toxicol Pharmacol. 2005;41:(3):185-227.

2. Schaal C, Chellappan S. Nicotine-Mediated Regulation of Nicotinic Acetylcholine Receptors in Non-Small Cell Lung Adenocarcinoma by E2F1 and STAT1 Transcription Factors. PloS one. 2016;11(5):e0156451.

3. Dasgupta P, Rastogi S, Pillai S, Dalia Ordonez-Ercan, Mark Morris, Eric Haura, et al. Nicotine induces cell proliferation by beta arrestin-mediated activation of Src and Rb-Raf-1 pathways. J Clin Invest. 2006;116(8):2208-2217. 4. Wang HY, Lee DH, Davis CB, Shank RP. Amyloid peptide Abeta (1-42) binds selectively and with picomolar affinity to alpha7 nicotinic acetylcholine receptors. J Neurochem. 2000;75(3):1155-61.

5. Baris S, Alroqi F, Kiykim A, KarakocAydiner E, Ogulur I, Ozen A, et al. Severe EarlyOnset Combined Immunodeficiency due to Heterozygous Gain-of-Function Mutations in STAT1. J Clin Immunol. 2016;36(7):641-8.

6. Ebner FH, Mariotto S, Darra E, H Suzuki, E Cavalieri. Use of STAT1 inhibitors in the treatment of brain I/ R injury and inflammatory and oxidative stress status of rat lung tissues. Induction of STAT1 pathway and the increase in oxidative stress may be the mechanisms through which Nicotine may induce its harmful effects.

\section{Acknowledgements}

We appreciate all the members of the central laboratory of Sohag Faculty of Medicine for their help. The work was financially supported by the departments of Medical Biochemistry and Medical Histology of Sohag university, Egypt.

The Ethics Committee of the Faculty of Medicine, Sohag University, Egypt approved the study (ethical approval number: $\mathrm{SOH}-$ IACUC-19070504).

The authors declare no conflict of interest.

neurodegenerative diseases. Cen Nerv Syst Agents Med Chem. 2011;11(1):2-7.

7. Wang H, Zhang Y, Xia F, Zhang W, Chen P, Yang G, et al. Protective effect of silencing STAT1 on high glucose-induced podocytes injury via Forkhead transcription factor O1regulated the oxidative stress response. BMC Mol and Cell Biol. 2019;20.

8. Schindler C, Fu XY, Improta T, R Aebersold, J E Darnell Jr. Proteins of transcription factor ISGF-3: one gene encodes the 91 -and $84-\mathrm{kDa}$ ISGF-3 proteins that are activated by interferon alpha. Proc Natl Acad Sci U S A. 1992;89(16):7836-9.

9. Baran-Marszak F, Feuillard J, Najjar I, Clorennec CL, Béchet JM, Dusanter-Fourt I, et al. Differential roles of STAT1alpha and STAT1beta in fludarabine-induced cell cycle arrest and apoptosis in human B cells. Blood. 2004;104(8): 2475-83.

10. Sayed Abdel-Tawab M, Mostafa Tork O, Mostafa-Hedeab G, Ewaiss Hassan M, Azmy Elberry D. Protective Effects of Quercetin and Melatonin on Indomethacin Induced Gastric Ulcers in Rats. rbmb.net. 2020; 9 (3) :278-290.

11. Islam T, Breton C, Salam MT, Rob McConnell, Made Wenten, W James Gauderman, et al. Role of inducible nitric oxide 
synthase in asthma risk and lung function growth during adolescence. Thorax. 2010;65(2):139-45. 12. Chen CW, Chang YH, Tsi CJ. et al. Inhibition of IFN-gamma-mediated inducible nitric oxide synthase induction by the peroxisome proliferator-activated receptor gamma agonist, 15-deoxy-delta 12,14-prostaglandin J2, involves inhibition of the upstream Janus kinase/STAT1 signaling pathway. J. Immunol. 2003; 171: 979988

13. de Prati AC, Ciampa AR, Cavalieri E, et al. STAT1 as a new molecular target of antiinflammatory treatment. Current medicinal chemistry. 2005; 12: 1819-1828.

14. Aydos, K., Guven, M. C., Can, B., et al. Nicotine toxicity to the ultrastructure of the testis inrats. BJU International.2001; 88:622-626.

15. Draper, H.H., Hadley, M. Malondialdehyde determination as index of lipid peroxidation. Methods Enzymol. (1990; 186: 421431.

16. Riddles P.W., Blakeley R.L., Zerner B. Reassessment of Ellman's Reagent Methods in Enzymology. 1983; 91 (C): 49-60.

17. Coussens, L.M., Werb, Z. Inflammation and cancer. Nature. 2002;420: 860-7.

18. Gomes, M., Teixeira, A. L., Coelho, A., et al. The role of inflammation in lung cancer. Advances in experimental medicine and biology. 2014; 816: 1-23

19. Akram, M., Kim, K.A., Kim, E.S., et al. Selective inhibition of JAK2/STAT1 signaling and iNOS expression mediates the antiinflammatory effects of coniferyl aldehyde. Chem Biol Interact. 2016; 256: 102-10.

20. Bozeman R, Abel EL, Macias E, Cheng T, Beltran L, DiGiovanni J, et al. A novel mechanism of skin tumor promotion involving interferon-gamma (IFN $\gamma)$ /signal transducer and activator of transcription-1 (STAT1) signaling. Molecular carcinogenesis 2015; 54: 642-653.

21. Moon H, White AC, Borowsky AD. New insights into the functions of Cox-2 in skin and esophageal malignancies. Exp Mol Med. 2020;52(4):538-547

22. Huang RY, Chen GG. Cigarette smoking, cyclooxygenase-2 pathway and cancer. Biochim Biophys Acta. 2011;1815(2):158-69.

23. Elisia I, Lam V, Cho B, Hay M, Li MY, Yeung M, et al. The effect of smoking on chronic inflammation, immune function and blood cell composition. Sci Rep. 2020;10(1):19480.

24. Hu Y, Tang J, Hou S, Shi X, Qin J, Zhang $\mathrm{T}$, et al. Neuroprotective effects of curcumin alleviate lumbar intervertebral disc degeneration through regulating the expression of iNOS, COX 2, TGF $\beta 1 / 2$, MMP 9 and BDNF in a rat model. Mol Med Rep. 2017;16(5):68646869.

25. Chen YC, Shen SC, Lin HY, Tsai SH, Lee TJF. Nicotine enhancement of lipopolysaccharide/interferon-gamma-induced cytotoxicity with elevating nitric oxide production. Toxicol Lett. 2004;153(2):191200.

26. Wetscher GJ, Bagchi M, Bagchi D, Perdikis G, Hinder PR, Glaser K, et al. Free radical production in nicotine treated pancreatic tissue. Free Radic Biol Med.1995;18(5):877-82.

27. Yildiz D, Liu YS, Ercal N, Armstrong DW. Comparison of pure nicotine- and smokeless tobacco extract-induced toxicities and oxidative stress. Arch Environ Contam Toxicol. 1999;37(4):434-9.

28. Bhagwat SV, Vijayasarathy C, Raza H, J Mullick, NG Avadhani. Preferential effects of nicotine and 4-(N-methyl-Nnitrosamine)-1-(3pyridyl)-1-butanone on mitochondrial glutathione S-transferase A4-4 induction and increased oxidative stress in the rat brain. Biochem Pharmacol. 1998;56(7):831-9.

29. Helen A, Krishnakumar K, Vijayammal PL, Augusti KT. Antioxidant effect of onion oil (Allium cepa. Linn) on the damages induced by nicotine in rats as compared to alpha-tocopherol. Toxicol Lett. 2000;116(1-2):61-8.

30. Kalra J, Chaudhary AK, Prasad K. Increased production of oxygen free radicals in cigarette smokers. Int J Exp Pathol. 1991; 72: 1-7.

31. Altuntas I, Dane S, Gumustekin K. Effects of cigarette smoking on lipid peroxidation. J Basic Clin Physiol Pharmacol. 2002;13(1):69-72.

32. Cheraghi M, Ahmadvand H, Maleki A, Babaeenezhad E, Shakiba S, Hassanzadeh F. Oxidative Stress Status and Liver Markers in Coronary Heart Disease. Rep Biochem Mol Biol. 2019;8(1):49-55.

33. Balcerczyk A, Bartosz G. Thiols are main determinants of total antioxidant capacity of 
cellular homogenates. Free Radic Res. 2003;37(5):537-41.

34. Ahmed Mobasher M, Galal El-Tantawi H, Samy El-Said K. Metformin Ameliorates Oxidative Stress Induced by Diabetes Mellitus and Hepatocellular Carcinoma in Rats. Rep Biochem Mol Biol. 2020;9(1):115-128

35. Kuschner WG, D'Alessandro A, Wong H, P D Blanc. Dose-dependent cigarette smokingrelated inflammatory responses in healthy adults. Eur Respir J.1996;9(10):1989-94.

36. Chaudhuri R, Livingston E, McMahon AD, Lafferty J, Fraser I, Spears M, et al. McMahon $\mathrm{AD}$, et al. Effects of smoking cessation on lung function and airway inflammation in smokers with asthma. Am J Respir Crit Care Med. 2006;174(2):127-33.

37. Westergaard CG, Porsbjerg C, Backer V. The effect of smoking cessation onairway inflammation in young asthma patients. Clin Exp Allergy. 2014;44(3):353-61.
38. Hogman M, Holmkvist $\mathrm{T}$, Walinder R, Meriläinen P, Lúdvíksdóttir D, Håkansson L, et al. Increased nitric oxide elimination from the airways after smoking cessation. Clin Sci (Lond). 2002;103(1):15-9.

39. Rennard SI, Daughton D, Fujit J, Oehlerking MB, Dobson JR, Stahl MG, et al. Short-term smoking reduction is associated with reduction in measures of lower respiratory tract inflammation in heavy smokers. Eur Respir J. 1990;3(7):752-9. 40. Karimi R, Tornling G, Grunewald J, et al. Cell recovery in bronchoalveolar lavage fluid in smokers is dependent on cumulative smoking history. PloS one. 2012;7(3):e34232. 